\title{
ВИКОРИСТАННЯ БІОПАЛИВА ГРОМАДСЬКИМ ДОРОЖНІМ ТРАНСПОРТОМ ЯК ОДИН $З$ ІНСТРУМЕНТІВ СТИМУЛЮВАННЯ ПОПИТУ НА БІОПАЛИВО В УКРАЇНІ
}

\author{
Г.С. Трипольська, канд. екон. наук, старший науковий співробітник
}

ДУ «Інститут економіки та прогнозування НАН України»,

01011, вул. П. Мирного, 26, м. Київ, Україна.

В статті розглянуто стан розвитку ринку біопалива в Украӥні. Підставами для виробництва біопалива в Украӥні є необхідність завантаження наявних иукропереробних заводів, створення та підтримка робочих місиь, покращення екологічної ситуаиії в містах та часткове заміщення імпорту викопних енергоносіїв. Метою статті є розрахувати, чи достатнім буде використання моторного біопалива в системі громадського дорожнього транспорту для виконання зобов'язань, передбачених Національним планом дій з відновлюваної енергетики на період до 2020 р. Це є особливо актуальним, зважаючи на те, щуо переважну частку бензину та дизпалива Украӥна імпортує, а практично усю вирощену в краӥні сировину для виробниитва біодизелю (в першу чергу ріпак) експортує. Визначено, що станом на 2019 рік біопаливо в Україні практично не вироблясться. Наявний іноземний досвід використання високих часток біологічного компонента в паливі аж до повного заміщення викопного палива (наприклад, паливо B100), яке виробляється для специфічних иільових груп, таких як автобуси, вантажівки тощо. На основі наявних статистичних даних та вжитих припущень було визначено, що використання біоетанолу громадським дорожнім транспортом для повного заміщення обсягу біопалива, визначеного Національним планом дій 3 відновлюваної енергетики не вбачається реальним, оскільки висока частка пасажирських автобусів знаходиться у приватній власності, а також через те, що автобуси технічно не пристосовані до використання високої частки біопалива. Відповідно, потрібні інші інструменти стимулювання використання біоетанолу, в першу чергу повернення вимоги домішування біологічного компонента палива. Визначено, щзо використання біодизелю громадським дорожнім транспортом може скласти лише $2 \%$ від необхідного розрахованого обсягу дизпалива. За умови наявності біодизелю на ринку, такий обсяг споживання дизпалива в системі громадського дорожнього транспорту досягти иілком реально. Бібл. 17, табл. 2, рис. 2.

Ключові слова: біопаливо, бензин, дизпаливо, ріпак, пасажирський транспорт

\section{USE OF BIOFUELS BY PUBLIC ROAD TRANSPORT AS ONE OF THE INSTRUMENTS TO STIMULATE THE DEMAND FOR BIOFUEL IN UKRAINE}

\author{
G. Trypolska, candidate of economic sciences, senior researcher
}

State Organization "Institute of the Economy and Forecasting of the National Academy of Sciences of Ukraine", 01011, 26, Panasa Myrnoho St., Kyiv, Ukraine

The paper focuses on the state of art of biofuels market development in Ukraine. The reasons for biofuels production in Ukraine are the need to load existing sugar refineries, create new and maintain the existing jobs, improve the environmental situation in cities and partially replace imports of fossil fuels. The purpose of the article is to calculate whether the use of motor biofuels in the public transport system (in particular, by buses) will be sufficient to meet the obligations provided for by the National Renewable Energy Action Plan for the period up to 2020. This topic is particularly timely, given that the predominant share of petrol and diesel is imported by Ukraine, and almost all of the country's biodiesel feedstock (first of all rape seed) grown in the country is exported. It is determined that by 2019 biofuels in Ukraine are practically not produced. There is foreign experience of use of high particles of a biological component in fuel up to the complete replacement of fossil fuels (eg. fuel B100), which is produced for specific target groups such as buses, trucks, and the like. Based on available statistical data and assumptions, the use of bioethanol by buses for the complete replacement of biofuels, as determined by the National Renewable Energy Action Plan, is proved unrealistic, as high share of passenger buses is privately owned, as well as because buses are technically not adapted to use a high proportion of biofuels. Accordingly, other tools to stimulate the use of bioethanol are needed, such as blending mandate requirement. The use of biodiesel by buses is calculated to reach only $2 \%$ of the required calculated amount of diesel fuel. Given the availability of biodiesel in the market, such a volume of diesel fuel consumption in the system of communal passenger transport is quite realistic. Ref. 17, tabl.2, fig. 2. Keywords: biofuel, gasoline, diesel fuel, rape, passenger transport. 


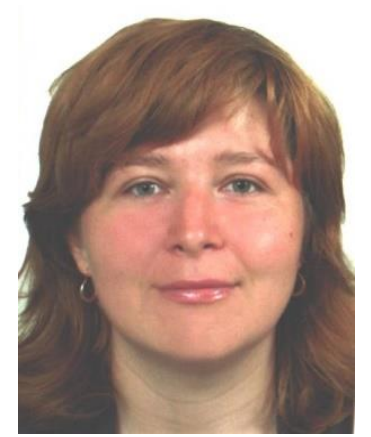

Г.С. Трипольська G. Trypolska
Відомості про автора: старший науковий співробітник, Сектор прогнозування розвитку паливно-енергетичного комплексу відділу секторальних прогнозів та кон'юнктури ринків, Державна установа "Інститут економіки та прогнозування НАН України".

Освіта: канд. екон. наук, ДУ «Інститут економіка та прогнозування НАНУ».

Наукова діяльність: питання державного регулювання ринку енергії з відновлюваних джерел України

Публікації: 13

ORCID: 0000-0002-8830-7036

Контакти: +380967972570

e-mail: g.trypolska@gmail.com

\section{Author information:}

Senior researcher, Sector of forecasting the development of fuel and energy complex, State Institution "Institute of Economics and Forecasting of NAS of Ukraine".

Education: candidate of economic sciences, Institute for Economics and Forecasting, UNAS

Research area: issues of state regulations of renewables market in Ukraine.

Publications: 13 .

ORCID: 0000-0002-8830-7036

Contacts: +380967972570

e-mail: g.trypolska@gmail.com
Вступ. Україна має зобов'язання з використання енергії з відновлюваних джерел, закріплені у прийнятому у 2014 p. Національному плані дій 3 відновлюваної енергетики на період до 2020 року. Ним визначені цілі щодо відновлюваної енергетики, зокрема Україна зобов'язалася до 2020 р. досягти рівня $11 \%$ енергії з відновлюваних джерел у загальній структурі енергоспоживання, а частка ВДЕ у транспортному секторі має становити $10 \%$.

Дослідженням питань державного регулювання ринку біопалива в Україні займаються такі науковці як В. Гавриш, О. Дячук, В. Месель-
Веселяк, Г.Калетнік, М.Кобець, О.Макарчук, Р.Подолець, Є.Рябцев, О.Шпичак та багато інших. Аргументами на користь використання біопалива в Україні є завантаження цукропереробних заводів, створення та підтримка наявних робочих місць (оскільки спиртзаводи та цукрозаводи часто $\epsilon$ містоутворюючими підприємствами), покращення екології міст, зменшення залежності від імпортованих енергоносіїв. Останній аргумент $€$ важливим, оскільки в Україну імпортується 90\% спожитого дизпалива та $62 \%$ бензинів (Рис.1).
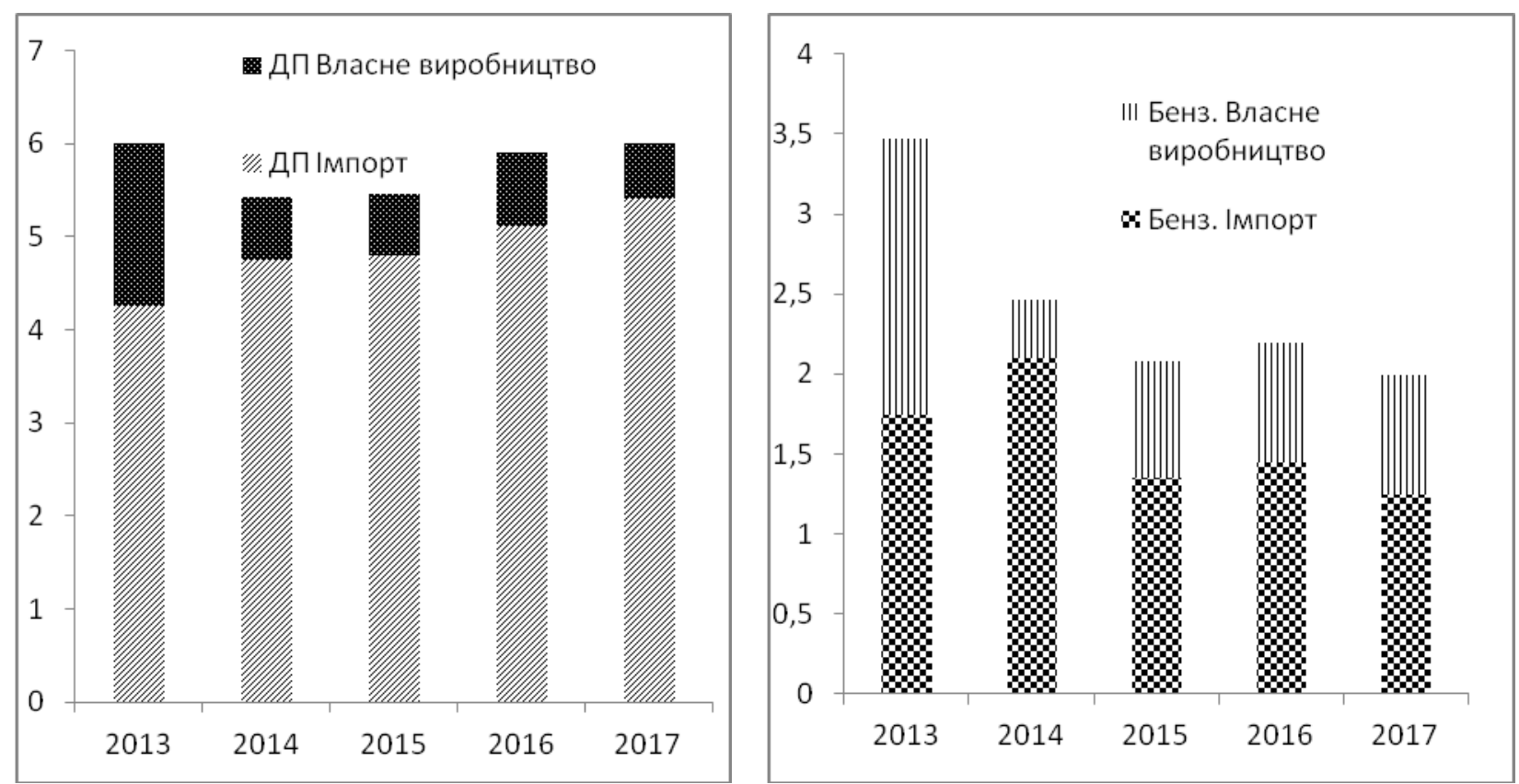

Джерело: вкладено на основі даних [3]

Рис. 1. Власне виробництво та імпорт дизпалива та бензину, млн $m$.

Fig. 1. Domestic output and import of diesel fuel and gasoline, million tons.

Стратегією $Є С$ щодо використання біологічного палива [8] визначено, що «міські та приватні автобусні парки ... досить легко можуть перейти на використання біопалива», тож використання біопалива в системі комунального транс- порту є важливим інструментом стимулювання попиту на біопаливо.

Постановка завдання. Дана стаття має на меті дослідити потенціал використання біопалива в системі громадського дорожнього транспорту в 
Україні, зокрема на автобусах і його роль у досягненні частки ВДЕ у транспортному секторі України на рівні $10 \%$.

Виклад основного матеріалу. В низці країн світу (напр., країни ЄС, США, Австралія) нерідко використовуються суміші 3 великою часткою біологічного компонента палива, такого як В20 та В30, що для СС регламентується стандартом EN 16709 (2015р.), який дозволяє використання сумішей В20 (20\% біологічного компонента палива) та В30 (30\% біологічного компонента палива). У Швеції поширене 100\% біопаливо B100, яке переважно напряму постачається великим споживачам 3 власними заправними станціями. Протягом 2015 р. у Швеції було спожито 425 тис м3 біодизелю, що склало $31 \%$ біопалива на ринку моторного палива. 3 них 247 тис м3 було спожито у вигляді сумішей, а 178 тис м3 - у вигляді В100 [12]. У вересні 2018 р. м. Стокгольм та регіон повністю відмовились від використання викопного палива в системі громадського транспорту - попит на енергоносії задовольняється переважно біодизелем, який використовується на 64\% автобусів (ще $15 \%$ автобусів їздяь на біогазі, а 21\% - на біоетанолі) [17]. Відомий великий ритейлер Tesco у Великобританії для перевезень використовує суміш B50. Шведські вантажівки Scania пристосовані до використання В100 [11]. У Франції поступово набуває популярності паливо E85, оскільки воно дешевше за бензин (так, на початку 2018 p. E85 було на 40\% дешевше, а протягом 2016-2017 рр. його продажі зросли на 23\%). Також 32016 р. у Франції почало продаватись паливо ED95, яке містить 95\% біоетанолу та 5\% хімреагентів та розроблено винятьково для автобусів та вантажівок зі спеціальними двигунами [14]. Високі суміші біопалива можуть використовувати як пристосовані автомобілі, так і може бути визначена вузька цільова група, що використовує паливо 3 високим вмістом біологічного компоненту. Так, у Словенії В100 використовується переважно великогабаритними вантажівками. В цілому, ж у СС $86 \%$ етанолу споживається транспортним сектором, а по 7\% промисловістю та продовольчим сектором [13].

Коротко розглянемо стан ринку біопалива в Україні. Біопаливо в нашій країні наразі практично не виробляється, хоча в 2013 р. єдиним джерелом постачання біопалива були українські виробники. Частка спожитого біопалива не перевищує $1 \%$, а наявне біопаливо переважно імпортується (Табл.1) [3]. Йдеться переважно про виробництво біоетанолу.

Таблиця 1. Виробництво та споживання біопалива в Україні у 2013-2017 рр., тис.т.

Table 1. Output and consumption of biofuels in Ukraine in 2013-2017, thousand tons.

\begin{tabular}{|l|l|l|l|l|l|}
\hline & 2013 & 2014 & 2015 & 2016 & 2017 \\
\hline Виробництво & 66 & 26 & 16 & 6 & 21 \\
\hline Імпорт & 0 & 38 & 46 & 58 & 54 \\
\hline Експорт & 0 & 0 & -9 & -6 & -4 \\
\hline Внутрішне споживання & 66 & 64 & 53 & 58 & 71 \\
\hline
\end{tabular}

Джерело: [3]

Біодизель практично не виробляється. В Україні наявний лише один виробник біодизелю, який пройшов сертифікацію відповідно до європейських критеріїв сталості сировини, а вироблений біодизель експортує до ЄС. Така сертифікація $\epsilon$ добровільною (для внутрішнього ринку). Українські лабораторії переважно не готові до масової сертифікації біопалива чи сировини для його виробництва. Одним з небагатьох винятків $є$ Бюро Верітас Україна, в той час як сертифікувати паливо 3 викопного палива до 2019 р. могли 43 лабораторії. Сертифікація стала можливою завдяки прийняттю у 2017 р. гармонізованих 3 європейськими критеріїв сталості для виробництва біопалив та біорідин для енер- гетичного використання [5]. Ці критерії включають оцінення відповідності, зокрема й ланцюжок відповідальності під час передавання товару та баланс маси; біорізноманіття та екологічні аспекти, пов'язані зі збереженням довкілля та методи обчислення балансу викидів парникових газів 3 використанням аналізу життєвого циклу продуктів.

Сировина для виробництва біодизелю теж переважно експортується до ЄС (Рис.2). Протягом липня-грудня 2018/2019 МР експорт ріпаку 3 України склав 2,3 млн т, що на $14 \%$ перевищує показник експорту аналогічного періоду 2017/2018 МР. Експорт ріпаку у 2018/2019 МР став найбільшим протягом останніх 10 років [1]. 


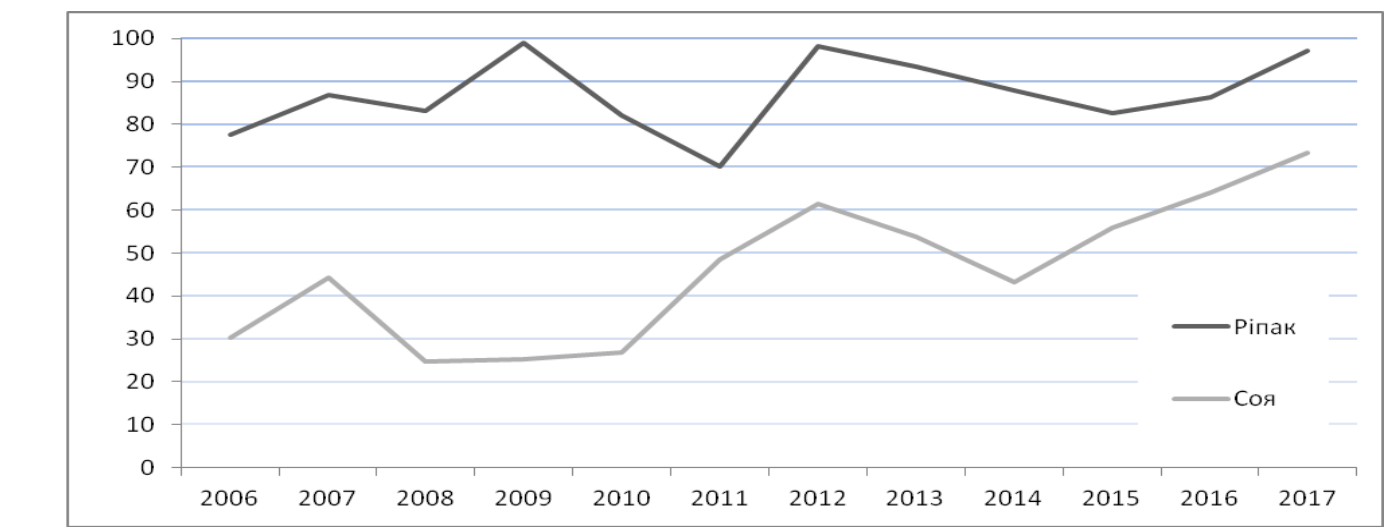

Джерело: укладено но основі даних [3]

Рис. 2. Частка експортованого насіння ріпаку та сої від загального виробництва у 2006-2017 рр., \%.

Fig. 2. Share of exported rape and soy seed in total output in 2006-2017, \%.

В Україні наявні потужності для виробництва етанолу в Україні, який, в тому числі, міг би використовуватися для потреб громадського дорожнього транспорту.
Станом на 2017 р. найбільшим виробником етанолу був Гайсинський спиртовий завод, виробивши у 2017 p. $65 \%$ усього етанолу (Табл.2).

Таблиця 2. Встановлена потужність та виробництво етанолу в Україні у 2017 р.

Table 2. Installed capacities and output of bioethanol in Ukraine in 2017.

\begin{tabular}{|l|c|c|c|}
\hline & $\begin{array}{c}\text { Встановлені } \\
\text { потужності, } m\end{array}$ & $\begin{array}{c}\text { Фактично } \\
\text { вироблено, } m\end{array}$ & $\begin{array}{c}\text { Завантаження } \\
\text { потужностей, \% }\end{array}$ \\
\hline Гайсинський С3 & 16800 & 18684 & 111 \\
\hline Івашківський С3 & 11610 & 2074 & 38 \\
\hline Зарубинський С3 & 14220 & 5471 & 0 \\
\hline Попівський Е3 & 7000 & 26 & 27 \\
\hline Хоростківське МПД ДП Укрспирт & 27840 & 482 & 0 \\
\hline Червоненський ЗПТ & 6900 & 1859 & 0 \\
\hline Барський СК & 16800 & & 0 \\
\hline Наумівський С3 & 9600 & & 0 \\
\hline Лохвицький СК & 14400 & & \\
\hline ТДВ "Узинський цукровий комбінат" & 7200 & & \\
\hline Разом & 132370 & 28596 & \\
\hline
\end{tabular}

Джерело: складено на основі [3].

Ліцензію на виробництво біоетанолу мають ДП «Зарубинський спиртовий завод», ТОВ «Агат-А», ТОВ «Біопаливно-енергетична компанія», ДП «Тростянецький спиртзавод», ПП «Нітробос». Ліцензію на виробництво етилового спирту (у т.ч. біоетанолу) мають 22 суб'єкти господарювання. Ліцензії видаються державною фіскальною службою [3]. Жодна 3 зазначених компаній не має ліцензії на імпорт біоетанолу: iï має лише ДП «Укрспирт». Домішувати біологічний компонент палива мають право лише підприємства, визначені Кабінетом Міністрів України. Наразі це ВАТ «Нафтохімік Прикарпаття», ВАТ «Лукойл-Одеський НПЗ», ВАТ «Херсоннафтопереробка», Шебелинське ВПГКН АТ «Укргазвидобування», ЗАТ «Укртатнафта» (Кременчуцький НПЗ). Навіть при тому, що станом на червень 2019 р. працювали лише два останніх підприємства, а фактично домішує біологічний компонент лише Кременчуцький НПЗ (та продає отриманий продукт на АЗС «Авіас»), цей перелік $\epsilon$ надзвичайно обмеженим та перешкоджає формуванню реальної інфраструктури 3 домішування біологічного компонента палива та формуванню ринку біопалива як такого. Отже, має бути або розширений перелік підприємств, що можуть домішувати біологічний компонент палива (шляхом внесення змін до статті 4 Закону України «Про підприємництво»), або скасоване положення про те, що КМУ має визначати перелік підприємств, що мають право домішування (для цього необхідно скасувати Постанову КМУ від 05.12.2007 №1375).

Відповідно до чинного законодавства, наявні вітчизняні стандарти допускають вміст біологічного компонента в бензині лише до 5\% (ДСТУ 4839:2007 «Бензини автомобільні підвищеної якості» [2]), а розроблений на основі Директиви 2009/28/СС9 проект ДСТУ «Біопаливо рідке та газове. Викиди парникових газів. Технічні вимо- 
ги» ще не затверджено.

Протягом 2018-2019 рр. законодавчих змін, що стосувалися б ринку моторного біопального, не відбулося. Єдиним винятком $є$ продовження на 2019 рік [7] дії Порядку використання коштів, передбачених у державному бюджеті для часткової компенсації вартості сільськогосподарської техніки та обладнання, спеціальних вагонів для перевезення зерна, обладнання для виробництва біоетанолу та електроенергії з біомаси, що закуплені у вітчизняних виробників [6]. Для фінансування даної Програми у 2019 р. виділено 900 млн грн. Разом $з$ обладнанням для виробництва біоетанолу дотується також і виробництво зерна. Для прикладу, у 2018 р. дотування виробництва зерна склало 960 млн грн., тож сумнівно, що у 2019 р., власне, залишаться кошти на відшкодування вартості обладнання для виробництва біоетанолу.

Перейдемо до розрахунку, який покаже, чи достатньо використання біопалива автобусами в системі пасажирського комунального транспорту для виконання положень Національного плану дій 3 відновлюваної енергетики на період до 2020 р. Для здійснення розрахунку було вжито такі припущення:

- Усереднена густина бензину $=0,74$ кг/л;

- Усереднена густина дизпалива - 0,769 кг/л;

- 1 т бензину складає 1,05 т.у.п. (т.н.е.) [15];

- 1 т дизпалива складає 1,01 т.у.п (т.н.е.) [15].

Національним планом дій 3 відновлюваної енергетики на період до 2020 року визначено, що для досягнення цілей 3 використання ВДЕ на 2020 рік у транспортному секторі обсяг використання біоетанолу має скласти 320 тис. т н.е., а біодизелю - 70 тис. т н.е. за умови річного споживання палива в обсязі 11 млн т/рік [4].

За даними Державної служби статистики України [9], загальний пробіг пасажирських автобусів підприємств і організацій України у 2016 р. склав 2025568,3 тис км, у тому числі пробіг з пасажирами - 1422156,6 тис км. Отже, для перевезення пасажирів було здійснено 70\% пробігу. За відсутності більш детальних статистичних даних припускаємо, що 3 загального пробігу пробіг, який здійснено на бензині склав 200775,6 тис км, а пробіг, який здійснено на дизельному пальному склав 1568923,1 тис км (70\% пробігу, здійсненого для перевезення пасажирів).

Відповідно до Норм витрат палива i мастильних матеріалів на автомобільному транспорті, затверджених наказом Міністерства транспорту України від 10 лютого 1998 р. № 43 (iз змінами і доповненнями, останні з яких унесено наказом Міністерства інфраструктури
України від 24 січня 2012 року № 36), середня базова лінійна норма витрат дизельного палива для автобусів складає 35,7 л/100 км, витрат бензину - 26,5 л/100 км.

Відповідно, для здійснення пасажирських перевезень у 2016 р. автобусами було використано приблизно 200775,6 тис км/0,265 л/км = $=757643773$ л бензину, або 757643773 л*0,74 кг/л/1000=560656 т.

За даними Євростату, 1 т бензину складає 1,05 т.н.е., тож 560656 т бензину становить 588689 т н.е.

Як зазначалося, для досягнення індикативних цілей 3 використання ВДЕ на 2020 рік у транспортному секторі обсяг використання біоетанолу має становити 320 тис. тне, або 54\% від розрахованого обсягу бензину, спожитого пасажирськими автобусами на бензині. На практиці такий високий рівень споживання $\epsilon$ сумнівним зважаючи на те, що висока частка пасажирських автобусів знаходиться у приватній власності, а також через те, що автобуси технічно не пристосовані до використання високої частки біопалива.

Для здійснення пасажирських перевезень у 2016 р. автобусами було використано приблизно 1568923,1 тис км $/ 0,357$ л/км $=4394742577$ л дизпалива, або $3076319803 \pi^{*} 0,769$ кг/л/1000 = $=3379557 \mathrm{~T}$

За даними Свростату, 1 т дизпалива складає 1,01 т.у.п., тож 3379557 т дизпалива становить 3413352 т у.п.

Як зазначалося, для досягнення індикативних цілей 3 використання ВДЕ на 2020 рік у транспортному секторі обсяг використання біодизелю має становити 70 тис. тне, або $2 \%$ від розрахованого обсягу дизпалива, спожитого пасажирськими автобусами на дизпаливі. За умови наявності біодизелю на ринку, такий обсяг споживання дизпалива тільки в системі громадського дорожнього транспорту досягти цілком реально.

3 наведених розрахунків слідує два додаткових важливих висновки:

- Для виконання НПДВЕ необхідні інші інструменти державного регулювання, особливо стосовно виробництва та споживання біоетанолу. Найбільш ефективним інструментом державного регулювання $є$ обов'язкова вимога домішування біологічного компонента. Протягом останнього десятиріччя вимоги домішування біопалива вважаються найбільш ефективним заходом регуляторної політики. Другим по значущості інструментом є вимоги щодо максимальних викидів $\mathrm{CO}_{2}$ від автомобілів, а третім - формування необхідної інфраструктури, зокрема заправнихстанцій [16]. 
А в Україні обов'язкову вимогу домішування біологічного компонента палива було скасовано у 2015 р., що зупинило розвиток даного ринку.

- Необхідне впровадження інших інструментів стимулювання попиту на біопаливо, таких як поширення інформації про позитивні ефекти від використання біопалива серед споживачів; впровадження стандартів біопалива; міжнародна торгівля біопаливом; надання пільгових позик виробникам біопалива; співпраця виробників біопалива $з$ автовиробниками; використання біопалива в системі державних закупівель [10].

Висновки. Використання біопалива громадським дорожнім транспортом $є$ важливим та дієвим способом стимулювання попиту на біопаливо. В той же час, для виконання вимог Національного плану дій з відновлюваної енергетики на період до 2020 р. використання високої частки біоетанолу автобусами не вбачається реальним, оскільки висока частка пасажирських автобусів знаходиться у приватній власності, а також через те, що автобуси технічно не пристосовані до використання високої частки біопалива. Відповідно, потрібні інші інструменти стимулювання використання біоетанолу, в першу чергу повернення вимоги домішування біологічного компонента палива, переведення автобусів на використання високих часток біологічних компонентів палива. Для уможливлення збільшення споживання біоетанолу зазначеною категорією транспортних засобів необхідна підтримка муніципальної чи державної влади. В той же час, використання біодизелю автобусами може скласти лише $2 \%$ від розрахованого обсягу дизпалива. За умови наявності біодизелю на ринку, такий обсяг споживання дизпалива в системі пасажирського громадського дорожнього транспорту досягти цілком реально.

1. Експорт українського ріпаку досягнув десятирічного максимуму. 2019. [Електронний ресурс]. URL https://agravery.com/uk/posts/show/eksport-ukrainskogo-ripakudosagnuv-desatiricnogo-maksimumu (дата звернення: 18.07.2019).

2. ДСТУ 4839:2007 Бензини автомобільні підвищеної якості. Технічні умови. [Електронний ресурс].

URL: $\quad$ http://energy-efficiency.in.ua/wpcontent/uploads/DSTUoil/dsty\%204839-2007.pdf

3. Зелена книга Регулювання виробництва рідких моторних біопалив. 2019. [Електронний ресурс]. URL: www.brdo.com.ua (дата звернення: 18.07.2019).

4. Лагутіна Н.М. Створення нормативно-правового підгрунтя для розвитку сфери виробництва рідкого біопалива. [Електронний ресурс]. URL: http://saee.gov.ua/sites/default/files/Lagytina.pdf (дата звернен ня: 18.07.2019).

5. Наказ ДП «Український науково-дослідний і навчальний центр проблем стандартизації, сертифікації та якості» від 28.07.2017 №197 «Про прийняття національних нормативних документів, гармонізованих з європейськими нормативними документами».

6. Постанова КМУ від 1 березня 2017 р. № 130 «Про затвердження Порядку використання коштів, передбачених у державному бюджеті для часткової компенсації вартості сільськогосподарської техніки та обладнання, спеціальних вагонів для перевезення зерна, обладнання для виробництва біоетанолу та електроенергії з біомаси, що закуплені у вітчизняних виробників».

7. Постанова КМУ від 30 січня 2019 р. № 123 «Про внесення змін до постанов Кабінету Міністрів України від 8 лютого 2017 р. № 77 і від 1 березня 2017 р. № 130».

8. Стратегія $\mathrm{CC}$ щодо використання біологічного палива. Повідомлення Комісії. Брюссель, хох СОМ(2006) 34 кінцевий.

9. Транспорт і зв'язок України - 2016. Статистичний збірник. Державна служба статистики України. Київ. 2017. 175 с.

10. Чибіскова Г.С. Стимулювання розвитку ринку біопалива в Україні. Автореферат дисертації на здобуття наукового ступеня кандидата економічних наук. Київ. 2009.

11. Bart J.C.J., Palmeri N., Cavallaro S. Biodiesel Science and Technology: From Soil to Oil. Woodhead Publishing Limited. 2011. 839 p. ISBN 978-1-84569-591-0.

12. В100 (Biodiesel). [Електронний ресурс]. URL: https://f3centre.se/app/uploads/fuels_fact_sheet_7_b100_170814 .pdf (дата звернення: 18.07.2019).

13. European Renewable Ethanol. Enabling Innovation and Sustainable Development. State of the industry. 2015. [Електронний ресурc]. URL: https://epure.org/media/1215/epure_ state industry2015 web.pdf (дата звернення: 18.07.2019).

14. Flach B., Lieberz S., Lappin J., Bolla S. EU-28 Biofuels Annual. EU Biofuels Annual 2018. 2018. [Електронний pecypc]. URL: https://gain.fas.usda.gov/Recent\%20GAIN\% 20Publications/Biofuels\%20Annual_The\%20Hague_EU-28_73-2018.pdf (дата звернення: 18.07.2019).

15. Glossary: Tonnes of oil equivalent (toe). [Електронний pecypc]. URL: https://ec.europa.eu/eurostat/statisticsexplained/index.php/Glossary:Tonnes_of_oil_equivalent_(toe) (дата звернення: 18.07.2019).

16. REN21. 2017 Renewables Global Futures Report: Great debates towards 100\% renewable energy (Paris: REN21 Secretariat). [Електронний pecypc]. URL: http://www.ren21.net/wp-content/uploads/2017/03/GFR-FullReport-2017.pdf (дата звернення: 18.07.2019).

17. Stockholm is the world's first capital with $100 \%$ fossil free bus services. [Електронний pecypc]. URL: https://www.biofuel-express.com/stockholm-is-the-worlds-firstcapital-with-100-fossil-free-bus-services/?lang=en (дата звернення: 18.07.2019).

\section{REFERENCES}

1. Eksport ukrainskoho ripaku dosiahnuv desiatyrichnoho maksymumu. [The export of Ukrainian rapeseed reached a ten-year high]. 2019. [Electronic resource]. URL: https://agravery.com/uk/posts/show/eksport-ukrainskogo-ripakudosagnuv-desatiricnogo-maksimumu. (Applying date: 18.07.2019). [in Ukrainian].

2. DSTU 4839:2007 Benzyny avtomobilni pidvyshchenoi yakosti. Tekhnichni umovy. [State All-Union Standard 4839:2007 High quality gasoline for vehicles. Specifications]. [Electronic resource]. URL: http://energyefficiency.in.ua/wp-content/uploads/DSTUoil/dsty\%204839-

2007.pdf. (Applying date: 18.07.2019). [in Ukrainian]

3. Zelena knyha Rehuliuvannia vyrobnytstva ridkykh motornykh biopalyv. [Green Book Regulation of output of liquid biofuels]. 2019. [Electronic resource]. URL: www.brdo.com.ua (Applying date: 18.07.2019). [in Ukrainian]. 
4. Lahutina N.M. Stvorennia normatyvno-pravovoho pidhruntia dlia rozvytku sfery vyrobnytstva ridkoho biopalyva. [Creation of legal and regulatory framework for the development of liquid biofuel production]. [Electronic resource]. URL: http://saee.gov.ua/sites/default/files/Lagytina.pdf. (Applying date: 18.07.2019). [in Ukrainian].

5. Nakaz DP «Ukrainskyi naukovo-doslidnyi i navchalnyi tsentr problem standartyzatsii, sertyfikatsii ta yakosti» vid 28.07.2017 №197 «Pro pryiniattia natsionalnykh normatyvnykh dokumentiv, harmonizovanykh z yevropeiskymy normatyvnymy dokumentamy». [Order of the State Enterprise "Ukrainian Research and Training Center for Standardization, Certification and Quality" dated 07/27/2017, №197 "On the Adoption of National Normative Documents Harmonized with European Regulatory Documents]. [in Ukrainian].

6. Postanova KMU vid 1 bereznia 2017 r. № 130 «Pro zatverdzhennia Poriadku vykorystannia koshtiv, peredbachenykh u derzhavnomu biu $\neg$ dzheti dlia chastkovoi kompensatsii vartosti silskohospodarskoi tekhniky ta obladnannia, spetsialnykh vahoniv dlia perevezennia zerna, obladnannia dlia vyrobnytstva bioetanolu ta elektroenerhii $\mathrm{z}$ biomasy, shcho zakupleni $\mathrm{u}$ vitchyznianykh vyrobnykiv». [CMU Resolution No. 130 of March 1, 2017 "On Approval of the Procedure for Using the Funds Envisaged in the State Budget for Partial Compensation for the Cost of Agricultural Machinery and Equipment, Special Grain Carriages, Equipment for the Production of Bioethanol and Electricity from Biomass, Purchased from domestic producers »]. [in Ukrainian].

7. Postanova KMU vid 30 sichnia 2019 r. № 123 «Pro vnesennia zmin do postanov Kabinetu Ministriv Ukrainy vid 8 liutoho 2017 r. № 77 i vid 1 bereznia 2017 r. № 130». [CMU Resolution No. 123 of January 30, 2019 "On Amendments to the Decrees of the Cabinet of Ministers of Ukraine of February 8, 2017 No. 77 and March 1, 2017 No. 130"]. [in Ukrainian].

8. Stratehiia YeS shchodo vykorystannia biolohichnoho palyva. Povidomlennia Komisii. Briussel, COM (2006) 34 kintsevyi. [EU strategy on the use of biofuels. Commission communication. Brussels, COM (2006) 34 final]. [in Ukrainian].

9. Transport i zviazok Ukrainy - 2016. [Transport and communications of Ukraine - 2016]. Statystychnyi zbirnyk. Derzhavna sluzhba statystyky Ukrainy Statistical collection. State Statistics Service of Ukraine. Kyiv. 2017. 175 p. [in Ukrainian]

10. Chybiskova G.S. Stymuliuvannia rozvytku rynku biopalyva v Ukraini. [Stimulation of development of the biofuel market Abstract of the dissertation for obtaining the scientific degree of the candidate of economic sciences. Kyiv. 2009. [in Ukrainian].

11. Bart J.C.J., Palmeri N., Cavallaro S. Biodiesel Science and Technology: From Soil to Oil. Woodhead Publishing Limited. 2011. 839 p. [in English]. ISBN 978-1-84569-591-0.

12. B100 (Biodiesel). [Electronic resource]. URL: https://f3centre.se/app/uploads/fuels_fact_sheet_7_b100_170814 .pdf (Applying date: 18.07.2019). [in English].

13. European Renewable Ethanol. Enabling Innovation and Sustainable Development. State of the industry. 2015. [Electronic resource]

URL:

https://epure.org/media/1215/epure_state_industry2015_web.pdf (Applying date: 18.07.2019). [in English].

14. Flach B., Lieberz S., Lappin J., Bolla S. EU-28 Biofuels Annual. EU Biofuels Annual 2018. 2018. [Electronic resource] URL:https://gain.fas.usda.gov/Recent\%20GAIN\%20Publication s/Biofuels\%20Annual_The\%20Hague_EU-28_7-32018.pdf. (Applying date: 18.07.2019). [in English].
15. Glossary: Tonnes of oil equivalent (toe). [Electronic resource]. URL: https://ec.europa.eu/eurostat/statisticsexplained/index.php/Glossary:Tonnes_of_oil_equivalent_(toe). (Applying date: 18.07.2019). [in English].

16. REN21. 2017 Renewables Global Futures Report: Great debates towards 100\% renewable energy (Paris: REN21 Secretariat). [Electronic resource]. URL: http://www.ren21.net/wp-content/uploads/2017/03/GFR-FullReport-2017.pdf. (Applying date: 18.07.2019). [in English].

17. Stockholm is the world's first capital with $100 \%$ fossil free bus services. [Electronic resource]. URL: https://www.biofuel-express.com/stockholm-is-the-worlds-firstcapital-with-100-fossil-free-bus-

services/?lang=en. (Applying date: 18.07.2019). [in English].

\section{ИСПОЛЬЗОВАНИЕ БИОТОПЛИВА ОБЩЕСТВЕН- НЫМ ДОРОЖНЫМ ТРАНСПОРТОМ КАК ОДИН ИЗ ИНСТРУМЕНТОВ СТИМУЛИРОВАНИЯ СПРОСА НА БИОТОПЛИВО В УКРАИНЕ}

Г.С. Трипольская, канд. экон. наук

ГО «Институт экономики и прогнозирования НАН Украины», 01011, ул. П. Мирного, 26 г. Киев, Украина.

В статье рассмотрено состояние развития рынка биотоплива в Украине. Основаниями для производства биотоплива в Украине есть необходимость загрузки имеющихся сахароперерабатывающих заводов, создание и поддержка рабочих мест, улучшение экологической ситуачии в городах и частичное замещение импорта ископаемых энергоносителей. Целью статьи является рассчитать, достаточным ли будет использование биотоплива в системе общественного дорожного транспорта для выполнения обязательств, предусмотренных Начиональным планом действий по возобновляемой энергетике на период до 2020 года. Это особенно актуально, учитывая то, что подавляющею долю бензина и дизтоплива Украина импортирует, а практически все выращенное в стране сырье для производства биодизеля (в первую очередь рапс) экспортирует. Определено, что по состоянию на 2019 год биотопливо в Украине практически не производится. Имеется зарубежный опыт использования высоких долей биологического компонента в топливе до полного замещения ископаемого топлива (например, топливо В100), которое производится для спеиифических иелевых групп, таких как автобусы, грузовики и тому подобное. На основе имеюшихся статистических данных и принятых предположений было определено, что использование биоэтанола общественным дорожным транспортом для полного замещения объема биотоплива, определенного Наииональным планом действий по возобновляемой энергетике не усматривается реальным, поскольку высокая доля пассажирских автобусов находится 6 частной собственности, а также из-за того, что автобусы технически не приспособлены к использованию высокой доли биотоплива. Соответственно, нужны другие инструменты стимулирования использования биоэтанола, 6 первую очередь возвращение требования примешивания биологического компонента топлива. Определено, что использование биодизеля общественным дорожным транспортом может составить всего $2 \%$ от необходимого рассчитанного объема дизтоплива. При наличии биодизеля на рынке, такой объем потребления дизтоплива в системе общественного дорожного транспорта достичь вполне реально. Библ. 17, табл. 2, рис. 2.

Ключевые слова: биотопливо, бензин, дизтопливо, panc, пассажирский транспорт.

Стаття надійшла до редакції 06.08.19 Остаточна версія 20.12.19 